had the gratification, and once at least the surprise, of seeing this work translated into other languages.

In 1906 Whittaker was appointed professor of astronomy in the University of Dublin, under the title of Royal Astronomer of Ireland. Though his duties pertained in a general way to astronomy, it was understood that his chief function was the strengthening of the school of mathematical physics. He therefore gave courses of advanced lectures, one of his pupils, whose future career was not to be in mathematics, being Mr. de Valéra. His principal work of these years, a work of piety and one that entailed an immense amount of reading and historical research, was his "History of the Theories of Aether and Electricity, from the Age of Descartes to the Close of the Nineteenth Century", published in 1910. This, together with its revision and amplification of 1951, and a second volume appearing in 1953 (his eightieth year) and bringing the history up to 1926 (thus just entering the Born-Heisenberg-JordanSchrödinger-Dirac period), must bo regarded as his magnum opus. The last sentence of this second volume reserved for a third volume an account of later developments up to 1950 ; but this, though the mental power remained, the physical strength was not sufficient to carry through.

On the death in 1911 of George Chrystal, professor of mathematics in the University of Edinburgh, Whittaker was elected his successor, entering on his duties in January 1912. He held this post for thirtyfive years, retiring in 1946. In Edinburgh he founded a school of research and, guided in part by the example of Runge in Germany on numerical analysis, a mathematical laboratory, at a time when this was an innovation in universities in Britain. With G. Robinson he published in 1924 a book, "The Calculus of Observations", based on the experience of the laboratory and his own knowledge of this field. Some of the incentivo, and a certain part of the material, came from his contact with actuaries in Edinburgh, in particular from his close friendship with the very distinguished actuary, the late Dr. G. J. Lidstone. $\mathrm{He}$ will, however, be chiefly remembered in Edin. burgh for his teaching, full of inspiration and flawless in delivery; he regarded it as incumbent on him to give lectures to classes at every level. At the same time, he took more than a full share in university administration and in membership of outside bodies.

On the Continent of Europe and in the United States Whittaker was very well known, and indeed kept up an extensive correspondence with mathematicians all over the globe. The mere enumeration of his honorary doctorates, fellowships, visiting lectureships or professorships, presidentships, foreign memberships and other distinctions would exceed the limits of space, and is available in any event in works of reference; much as he valued his well-deserved medals, the Sylvester, the De Morgan, the Copley and others, he appeared to be specially touched and warmed by the honorary fellowship of Trinity College, bestowed on him in his later years and reminding him of his earlier. He was knighted in 1945.

After 1930, when he was received into the Roman Catholic Church, Whittaker's interests turned to natural theology; several of his essays and books of this period, such as "Space and Spirit", have as their explicit aim the reconciliation of modern natural and cosmological science with religion. These preoccupations are a mark of the underlying seriousness of his character. In mind he was clear and rapid to a quite exceptional degree; his capacity for industry was equally beyond the normal; not least he possessed a Roman pietas, exercised not only in seeing justice done to the most obscure of his remote precursors in natural philosophy, but also to those close at hand, as when - to choose but one instancehe took up and edited the posthumous manuscripts of Eddington, thus producing the book, "Fundamental Theory". In manner he was unfailingly courteous, yet not formal ; entirely accessible and sympathetic.

He is survived by Lady Whittaker, daughter of the Rev. Thomas Boyd and granddaughter of Sir Thomas Jamieson Boyd, of Edinburgh, and by three sons and two daughters. His socond son, Dr. J. M. Whittaker, formerly professor of mathematics in the University of Liverpool, is now vice-chancellor of the University of Sheffield.

A. C. Aitiken

\section{Prof. A. M. Blackman, F.B.A.}

Prof. A. M. Blackman, who died at Abergele on March 9 at the age of seventy-three, was almost the last surviving member of the older generation of British Egyptologists whose researches and publica. tions during the past sixty years have so widely extended our knowledge of Ancient Egypt and early man.

Aylward Manley Blackman was born on January 30 , 1883, the eldest son of the Rev. J. H. Blackman, and until he was sixteen was educated privately. He then entered St. Paul's School, whence he obtained a scholarship to Queen's College, Oxford. Under the influence of his father, a keen amateur archæologist, Blackman had at a very early age acquired an abiding interest in Egypt and in archæology, and hence on going to Oxford it was not surprising that he should have read Egyptian, Coptic and Arabic. In 1906, he obtained a first class in Oriental studies.

Blackman's first few years after graduation were busily spent in Nubia and Egypt. During 1907-8 he was one of the assistants of the late Prof. G. A. Reisner on the first of the great expeditions of the Archæological Survey of Nubia and thus obtained practical field-experience in a very hard school. During 1909-10 he helped in the excavations by the University of Pennsylvania at Buhen, slightly to the south of Wadi Halfa, and was solely responsible for the inscriptional work of the expedition. 1910, in fact, was an intensely busy year for him. In that year he was elected Oxford University Nubian Research Scholar and participated in the Oxford Excavations at Faras, a few miles north of Wadi Halfa on the Egypto-Sudan frontier. Almost simultaneously he became one of the international team of scholars engaged in recording those of the Nubian temples that the building of the Assuan Dam threatened to submerge. Between January and May, 1910, by dint of prodigious physical effort and at the cost of sickness the effects of which never left him for the rest of his life, he recorded all the scenes and inscriptions in the temples of Bigeh, Dendur and Derr (all published betwoen 1911 and 1915), and began but nover completed the record of the temple of Gerf Hussein.

In 1912, he was elected Laycock Student of Egypt. ology at Worcester College, Oxford, and in the same year he began, on behalf of the Egypt Exploration Society, the copying of the inscriptions of the important group of rock tombs at Meir in Middle Egypt. His work at Meir occupied the seasons 1912-14, 
1921 and 1949-50, and the results were published in a series of six volumes between 1914 and 1953 .

In 1934, he was elected Brunner professor of Egypt. ology in the University of Liverpool, and held this post until his retirement in 1948. Academic and other responsibilities limited his opportunities of visiting Egypt; but 1936-37 saw him once again in the Sudan as director of the Egypt Exploration Society's excavations at Sesebi.

Blackman's main scientific interest was in the religion of Ancient Egypt, particularly its liturgy and ritual. Unfortunately, he never wrote a book on the subject that was nearest to his heart; but his most important contributions to Egyptology certainly lie in the numerous papers which he contributed to the leading Egyptological journals. Typical of these are his massive contributions on such subjects as "Priesthood", "Purification" and "Worship" to Hastings's "Encyclopædia of Religion and Ethics" which still retain all their freshness and value.

$\mathrm{He}$ was a magnificent teacher. $\mathrm{He}$ liked young people, and his deep knowledge of his subject, coupled with a lively and warm sympathy with and understanding of his students, made him an inspiring teacher. Above all, he was interested in showing that Ancient Egypt was alive: to him there were no dead bones in archæology, and this was reflected not only in his scientific papers, but also in his popular writings, such as his delightful "Luxor and its Temples" (1923), which was also translated into German, his "Literature of the Ancient Egyptians" (1927), a translation of Erman's original work and still the only book of its kind in English, and in his inaugural lecture, "The Value of Egyptology in the Modern World" (1936). Of all British Egyptologists, he was possessed of a real sense of style and language: his translations, even if they had perhaps rather too strong a Biblical flavour, were vivid, accurate and attractive, and his commentaries displayed that same gift of expression allied to deep learning.

Blackman's last years were clouded with tragedy and misfortune. When returning from Meir in 1950 he broke his hip on board ship, and returned home on a stretcher, only to discover that his home had been broken up by the tragic fate of his sisters. Throughout his life he had been peculiarly devoted to his family: this double blow was one from which he never really recovered, and his years of retirement were marked by increasing physical weakness and pain. His election in 1952 as a Fellow of the British Academy was a recognition of his contributions to Egyptology that brought him great cheer in his last difficult years. A great scholar, an inspiring teacher, a very human and kindly man, deeply religious, and in private life the most unselfish and sincere of friends, his death removes one of very great gifts whose place, in his own special field, it will be hard to fill.

$$
\text { H. W. Fatrman }
$$

\section{Prof. Samson Wright}

THE sudden death on March 11 of Prof. Samson Wright came as a great shock to his many friends; he was fifty-six years of age.

Samson Wright ('Sammy' to his colleagues) entered the Middlesex Hospital Medical School as a student in 1916 and, apart from one year when he was lecturer in physiology at King's College in 1929, he remained at the Middlesex until his death. After gaining the Gold Medal in the M.B., B.S. examination in 1922, he became senior demonstrator in the Department of Physiology under the late Prof. Swale Vincent, and, after his brief sojourn at King's College, he was appointed as the first John Astor professor of physiology at the Middlesex Hospital Medical School when Prof. Swale Vincent retired in 1930. In 1931 ho gave the Oliver-Sharpey Lecture at the Royal College of Physicians on "Certain Aspects of the Reflex Control of the Circulation" and in 1933 he was elected a Fellow of the College.

Wright's services to physiology were many; but there is no doubt that his greatest contribution was as a teacher. Both as a lecturer and as the author of the well-known "Applied Physiology" (first published in 1926 and now in its ninth edition) he was supreme. His vast knowledge, his critical insight and his fluent exposition could make the most difficult topic seem simple, and he had a wonderful gift for stimulating others to think for themselves. $\mathrm{He}$ believed that physiology was the corner-stone of medicine, and his classic text-book is a vivid commentary on this theme.

During 1938-4.9 Wright served the Physiological Society as editor of Physiological Abstracts, and during this difficult time he developed it into an indispensable scientific publication.

Samson Wright made notable original contributions to the physiology of the circulation, respiration and the central nervous system. In his early work on the circulation, he was the first to show that ergotamine abolishes the response of the vasomotor centre to sino-aortic afferent impulses. His most important work on respiration was the demonstration with Selladurai that anoxic hyperpnoea is entirely dependent on chemoreceptors, whereas carbon dioxide hyperpnoa is unaffected by sino-aortic nerve section. He also studied the action of acetylcholine and related compounds on chemoreceptors and put forward the hypothesis that acetylcholine might be the transmitter substance in the glomus.

Wright worked with various colleagues for many years on the complex problem of chemical transmission within the central nervous system, and studied the actions of anticholinesterases such as eserine, neostigmine and diisopropylfluorophosphonate. They suggested that the differences between the central actions of the first two drugs were due to the fact that eserine is a tertiary compound which penetrates cell membranes easily, whereas neostigmine is a quaternary compound which does not.

Recently he had been investigating the effects of injection of $d$-tubocurarine into various parts of the brain as revealed by electrical wave patterns recorded from different areas.

Apart from his own work, Wright was a most inspiring and enthusiastic director of research, though he was very eritical of anything which fell below his own high standards.

Wright had many interests outside physiology. $\mathrm{He}$ was an enthusiastic Zionist and he did all that was humanly possible to help those Jewish refugees who came to Britain from Hitler's Germany. After the establishment of the State of Israel, he took a great interest in the Hebrew University of Jerusalem, of which he was a governor. He was also vice-chairman in Britain of the Friends of the Hebrew University. He helped to build up the University's Faculty of Medicine along traditional British lines, and it is most fitting that a laboratory in its Department of Physiology was recently named after him. 